\title{
SYARIAH CARD PESRPEKTIF AL-MAQASID SYARIAH
}

\author{
Ulul Azmi Mustofa
}

Program Studi Ekonomi Islam STIE AAS Surakarta

\begin{abstract}
Islamic Banking in this era is booming. Also its product, such as product Syariah Card (Islamic Credit Card). This paper examines a system and concept Syariah Card with alMaqhasid Syariah Perspective. We found a Syariah card concept is acceptable with Fiqh concept, but there are many qualifyings. One of The qualifying is must consumer priority, meaning is consumer not be improvident.
\end{abstract}

Key Word : Syariah Card, al-Maqhasid Syariah

\section{PENDAHULUAN}

\section{A. Latar Belakang}

Usaha perbankan memiliki tujuan menjawab kebutuhan-kebutuan masyarakat, setiap hari selalu ada langkah maju dan fasilitas-fasilitas baru yang digunakan untuk kepentingan tersebut. Salah satu fasilitas adalah kartu kredit. Bank-bank dan lembaga-lembaga keuangan menyediakan kartu kredit untuk melakukan transaksi pembelian tanpa harus mengeluarkan uang tunai. Sistem kartu kredit adalah suatu jenis penyelesaian transaksi ritel (retail) dan sistem kredit, yang namanya berasal dari kartu plastik yang diterbitkan kepada pengguna sistem tersebut. Kartu kredit berbeda dengan kartu debit di mana penerbit kartu kredit meminjamkan konsumen uang dan bukan mengambil uang dari rekening. Kebanyakan kartu kredit memiliki bentuk dan ukuran yang sama.
Fungsi uang ini amat beragam dan amat dibutuhkan dalam perekonomian, perdagangan maupun perbankkan. Dalam dunia perbankan misalnya, perbankan mempunyai tiga fungsi utama yaitu, sebagai penerima simpanan uang, meminjamkan uang, dan memberikan jasa memerlukan mata uang yang likuiditas dan kenetralan yang tinggi. ${ }^{1}$

Dewasa ini, dunia perbankan dalam perkembangannya telah mengalami perubahan yang sangat pesat, dimana uang menjadi obyek dari perbankan telah mengalami perubahan yang lebih modern. Peranan uang dalam perekonomian antara lain dapat meningkatkan efisiensi baik bagi produsen, konsumen dan kegiatan ekonomi masyarakat pada umumnya.

Karena kemudahannya, Bisnis kartu pembiayaan (kredit) perbankan

${ }^{1}$ Adiwarman Karim. 2005. Bank Dan Lembaga Keuangan Lainnya. (Jakarta: PT Grafindo Persada).hlm. 18. 
syariah sangat diminati nasabah sehingga targetnya melampaui batas. Peningkatan ini di amini oleh Bambang Widjanarko, Direktur Bisnis PT BNI Syariah, mengatakan, transaksi kartu pembiayaan BNI Syariah atau dikenal dengan produk Hasanah Card, mengalami lonjakan drastis selama Agustus 2011. Dia mencatat kenaikan transaksi sebesar 35\% dibanding bulan-bulan biasanya. ${ }^{2}$

Namun, bisnis ini dinilai mendorong konsumsi di luar kemampuan nasabah yang tidak sesuai dengan prinsip ekonomi Syariah itu sendiri. Munculnya kartu kredit dengan beragam manfaat dan macamnya memberikan berbagai kebaikan sekaligus keburukan. Manfaat kartu kredit dapat menghemat waktu, ketelitian hitungan, dan kenyamanan konsumen kartu. ${ }^{3}$ Sebaliknya, Keburukan munculnya kartu kredit adalah munculnya sifat boros bagi nasabah yang menggunakannya, perlu pemilahan konsumen untuk menghindarinya. Selanjutnya peran bankbank dan lembaga-lembaga keuangan sangat diperlukan untuk memberikan klasifikasi ketat bagi nasabah kartu kredit agar sifat boros dapat dihindari.

\section{B. Rumusan Masalah}

Makalah ini akan membahas beberapa permaslahan tentang Syariah Card, yaitu: Bagaimana Konsep dan sistem Syariah Card? Dan Bagaimana penerapan

\footnotetext{
${ }^{2}$ Lihat,

http://www.indonesiafinancetoday.com/read/15109/ Bisnis-Kartu-Pembiayaan-Bank-Syariah-MelebihiTarget, diakses pada 30 Juli 2012

3 Sayyid Abbas Musawiyan. 2012. Sistem Perbankan Islam Berkaca Pada Iran Hal. 408
}

Syariah Card jika ditinjau dari Maqhasid Syariah?

\section{Batasan Masalah}

Penelitian ini hanya membahas tentang konsep dan sistem akad yang difatwakan oleh DSN MUI, dan melihat bagaimana aplikasinya dalam perbankan Syariah di Indonesia, yang kemudian dianalisa dengan al-maqashid Syariah dilihat dari tingkatannya, yaitu alDhoruriyah, al-Hajatiyah, dan alTahsiniyah.

\section{LANDASAN TEORI}

\section{A. Syariah Card.}

Kartu kredit dalam bahasa arab adalh bithaqah I'timan. Dalam Fiqih Muamalah diartikan sebagai memberikan hak kepada orang lain atas hartanya dengan ikatan kepercayaan, sehingga orang tersebut tidak bertanggung jawab kecuali bila ia melakukan keteledoran atau pelanggaran. Transaksi itu sendiri menurut ulama fiqh adalah transaksi bebas bukan transaksi penyerahan hak. Misalnya dikatakan kepada seseorang, "silahkan beli barang saya ini seperti kamu biasa membelinya dari orang lain karena saya tidak mengerti harga." maka ia membelinya dengan harga yang biasa ia keluarkan untuk membeli barang sejenis. Dalam kebiasaan dalam dunia usaha artinya semacam pinjaman, yakni yang berasal dari kepercayaan terhadap peminjam dan sikap amanahnya serta kejujurannya. Oleh sebab itu ia memberikan dana itu dalam bentuk pinjaman untuk dibayar secara tertunda.

Pengertian kartu kredit Dalam

Expert Dictionary didefinisikan: "kartu 
yang dikeluarkan oleh pihak bank dan sejenisnya untuk memungkinkan pembawanya membeli barang-barang yang dibutuhkannya secara hutang. Sementara dalam kamus Ekonomi Arab menjelaskan, "sejenis kartu khusus yang dikeluarkan oleh pihak bank-sebagai pengeluar kartu-, lalu jumlahnya akan dibayar kemudian. Pihak bank akan memberikan kepada nasabahnya itu rekening bulanan secara global untuk dibayar, atau untuk langsung didebet dari rekeningnya yang masih berfungsi."

Dalam Peraturan Bank Indonesia Nomor 11/11/PBI/2009 tentang Penyelenggaraan Alat Pembayaran dengan Menggunakan Kartu, pada Pasal 1 angka (4), yang dimaksud dengan kartu kredit (credit card) adalah Alat Pembayaran Dengan Menggunakan Kartu yang dapat digunakan untuk melakukan pembayaran atas kewajiban yang timbul dari suatu kegiatan ekonomi, termasuk transaksi pembelanjaan dan/atau untuk melakukan penarikan tunai dimana kewajiban pembayaran Pemegang Kartu dipenuhi terlebih dahulu oleh acquirer atau penerbit, dan Pemegang Kartu berkewajiban melakukan pelunasan kewajiban pembayaran tersebut pada waktu yang disepakati baik secara sekaligus (charge card) ataupun secara angsuran.

Syariah Card adalah fasilitas kartu
talangan yang dipergunakan oleh
pemegang kartu (hamil al-bithaqah)
sebagai alat bayar atau pengambilan uang
tunai pada tempat-tempat tertentu yang
harus dibayar lunas kepada pihak yang

memberikan talangan (mushdir al-bithaqah) pada waktu yang telah ditetapkan. ${ }^{4}$

Alhasil, Syariah Card dapat diartikan sebagai kartu yang berfungsi seperti kartu kredit yang hukumnya berdasarkan prinsip Syariah. Adapun terkaitan para pihak adalah penerbit kartu atau Mushdir al-bithaqah, pemegang kartu atau hamil al-bithaqah, dan penerima kartu dalam hal ini merchant baik itu pusat perbelanjaan, took, dan lain sebagainya atau Tajir/Qabil al-Bithaqah.

Kemudian ada ketentuan oleh DSN-MUI mengenai diperbolehkannya pengenaan fee atas transaksi yang terjadi. Penerbit kartu diperbolehkan mengenakan membership fee, yaitu iuran keanggotaan termasuk perpanjang masa keanggotaan dari pemegang kartu, sebagai imbalan izin menggunakan kartu yang pembayarannya berdasarkan kesepakatan. Merchan fee pun diperbolehkan, pemberian merchant kepada penerbit kartu sehubungan transaksi yang menggunakan kartu sebagai upah/imbalan atau ujrah atas jasa perantara, pemasaran, dan penagihan.

$$
\text { Sedangkan jika terjadi }
$$

keterlambatan pembayaran yang sudah jatuh tempo, maka penerbit boleh menggunakan Ta'wid atau ganti rugi terhadap biaya-biaya yang dikeluarkan oleh penerbit kepada pemegang kartu. Begitu pula pemberian denda karena keterlambatan pembayaran yang akan diakui sebagai dana sosial bukan menjadi hak bank.

\footnotetext{
${ }^{4}$ Fatwa Dewan Syari'ah Nasional No:
} 54/DSN-MUI/X/2006 Tentang Syariah Card 


\section{B. Ketentuan Akad Syariah Card}

\section{Akad Kafalah}

Kafalah memiliki banyak sekali padanan kata antara lain Hammalah, dhomanah, dan za'amah. Menurut madzhab Hanafi, Kafalah adalah memasukkan tanggung jawab seseorang ke dalam tanggung jawab orang lain dalam suatu tuntutan hukum, ${ }^{5}$ dalam artian menyertakan orang lain untuk ikut menanggung tanggung jawab orang lain berkaitan dengan nyawa, harta atau barang. Adanya penjaminan tersebut tidak serta merta menjadikan yang terhutang bebas dari hutang dan yang bertanggung jawab atas hutang seseorang menjadi orang yang berhutang, dalam artian bahwa yang berhutang tetap berhutang sedangkan penjamin tidak.

2. Akad Qard

Al-Qard adalah suatu akad pinjaman kepada nasabah tertentu dengan ketentuan nasabah wajib mengembalikan dana yang diterimanya kepada lembaga keuangan Syariah pada waktu yang telah disepakati oleh LKS dan Nasabah.Dalam kamus Istilah Keuangan dan Perbankan Syariah, Bank Indonesia menjelaskan Qard sebagai berikut, Qard (Pinjaman) adalah suatu akad yang menjamin ketentuan pihak yang menerima pinjaman wajib mengembalikan dana sebesar yang diterima.

Selanjutnya, akad Qard dapat juga disebut dengan akad yang memberikan pinjaman kepada orang

5 Wiroso. 2009. Produk Perbankan Syariah. (Jakarta: LPFE Usakti). Hal. 347 lain tanpa adanya harapan untuk mendapat imbalan dari pinjaman tersebut.

3. Akad ijarah

Ijarah adalah akad sewamenyewa antara pemilik Ma'jur dan Musta'jir untuk mendapatkan imbalan atas obyek sewa yang disewakan. Kemudian dalam kamus istilah keuangan dan perbankan syariah mendefinisikan Ijarah adalah akad pemindahan hak guna (manfaat) atas suatu barang atau jasa dalam waktu tertentu melalui pembayaran sewa upah, tanpa diikuti dengan pemindahan kpemilikan barang itu sendiri. ${ }^{6}$

Dalam PSAK 107 (ED) tentang akuntansi Ijarah memberikan pengertian Ijarah sebagai berikut: "ijarah adalah akad pemindahan hak guna (manfaat) atas suatu asset dalam waktu tertentu dengan pembayaran sewa (ujrah) tanpa diikuti dengan pemindahan kepemilikan asset itu sendiri.

Dalam Accounting Auditing for Islamic Financial Institution (AASIFI) yang dikeluarkan oleh Accounting and Auditing Organization for Islamic Financial Institutions (AAOIFI), menjelaskan tentang pengertian ijarah sebagai berikut: "sewa adalah apa yang dijanjikan untuk dibayar oleh Penyewa sebagai suatu imbalan atas manfaat yang dinikmati. Segala sesuatu yang tepat untuk dipandang sebagai harga di dalam suatu penjualan bisa dianggap sebagai sewa di dalam suatu Ijarah." Mayoritas Fuqaha mengatakan: "syaratsyarat yang berlaku bagi harga juga

\footnotetext{
${ }^{6}$ Ibid. hal. 248
} 
berlaku bagi sewa". 7 Sewa harus diketahui, jika manfaat diketahui dan sewa tersebut tidak ditentukan, maka sewa untuk manfaat yang sama harus di bayarkan.

\section{Maqasid Syariah}

Menurut Wahbah al Zuhaili, Maqasid Al Syariah berarti nilai-nilai dan sasaran syara' yang tersirat dalam segenap atau bagian terbesar dari hukum-hukumnya. Nilai-nilai dan sasaran-sasaran itu dipandang sebagai tujuan dan rahasia syariah, yang ditetapkan oleh al-Syari' dalam setiap ketentuan hukum. ${ }^{8}$ Menurut Syathibi tujuan akhir hukum tersebut adalah satu, yaitu mashlahah atau kebaikan dan kesejahteraan umat manusia. ${ }^{9}$

Mayoritas ulama membagi kemashlahatan menjadi dua macam. Pertama, kemashlahatan akhirat yang dijamin oleh akidah dan ibadah dan kemashlahatan dunia yang dijamin oleh muamalat. Kemashlahatan yang menjadi tujuan syariat ini dibatasi dalam lima hal, agama, jiwa/nafs, akal, keturunan dan harta. Setiap hal yang mengandung penjagaaan atas lima hal ini disebut maslahah dan setiap hal yang membuat hilangnya lima hal ini disebut mafsadah. ${ }^{10}$

Setiap hal yang menjadi perantara terjaganya lima hal ini, dibagi menjadi tiga

\footnotetext{
${ }^{7}$ Ibid. hal. 249

${ }^{8}$ Wahbah Zuhaili, Ushul Fiqh Islamy, Damaskus: Dar al Fikr, 1986, juz 2 hal 225

${ }^{9}$ Muhammad Khalid Mas'ud, Filsafat Hukum Islam dan Perubahan Sosial, terjemahan oleh Yudian W. Asmin, Surabaya: Al Ikhlas, 1995, hal.225

${ }^{10}$ Muhammad Said Romadlon al Buthi, Dhowabit al Mashlahah fi al Syariah al Islamiyah, Beirut: Dar al Muttahidah, 1992 hal 110
}

tingkatan kebutuhan yaitu al-Dlorruriyat, al-Hajiyat dan al-Tahsinat. ${ }^{11}$

1. Kebutuhan al-Dhoruriyat

Kebutuhan al-Dhoruriyat adalah tingkat kebutuhan yang harus ada atau disebut juga kebutuhan primer. Apabila tingkat kebutuhan ini tidak terpenuhi maka keselamatan ummat manusia akan terancam, baik di dunia maupun di akhirat. Menurut Al Syatibi ada lima hal yang termasuk dalam kategori ini yaitu memelihara agama, jiwa, kehormatan, keturunan dan harta. Untuk memelihara lima hal pokok inilah syariat Islam diturunkan. Dalam setiap ayat hukum apabila diteliti akan ditemukan alasan pembentukannya yang tidak lain adalah untuk memelihara lima hal pokok di atas. Seperti kewajiban qisas:

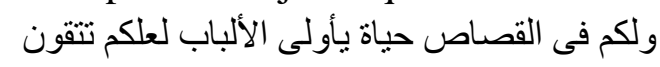

"Dan dalam qisas itu ada (jaminan kelangsungan) hidup bagimu hai orangorang yang bertakwa"12

Dari ayat ini dapat diketahui bahwa disyariatkannya qisas karena dengan itu ancaman terhadap kehidupan manusia dapat dihilangkan.

2. Kebutuhan al hajiyat

Al Syatibi mendefinisikan sebagai kebutuhan sekunder. Jika kebutuhan ini tidak terpenuhi keselamatan manusia tidak sampai terancam. Namun ia akan mengalami kesulitan. Syariat Islam menghilangkan segala kesulitan tersebut. Adanya hukum rukhshah (keringanan) seperti dijelaskan Abdul Wahhab Khallaf. 
Merupakan contoh kepedulian syariat Islam terhadap kebutuhan ini.

3. Kebutuhan al tahsinat

Definisinya adalah kebutuhan yang tidak mengancam eksistensi salah satu dari lima hal pokok tadi dan tidak pula menimbulkan kesulitan apabila tidak terpenuhi. Tingkat kebutuhan ini berupa kebutuhan pelengkap, seperti dikemukakan al-Syatibi seperti hal yang merupakan kepatutan menurut adatistiadat menghindari hal yang tidak enak dipandang mata dan berhias dengan keindahan yang sesuai dengan tuntutan norma dan akhlak, dalam berbagai bidang kehidupan seperti ibadah muamalah, dan uqubah.

\section{ANALISIS DAN PEMBAHASAN SYARIAH CARD}

\section{A. Mekanisme Syariah Card di Perbankan Syariah}

Berkenaan dengan transaksi Syariah Card terdapat tiga pihak sekaligus yang saling berkaitan, yaitu penerbit kartu, pemegang kartu, dan Merchant. Adanya ketiga pihak sekaligus yang menyertai produk Syariah Card otomatis akan memberikan konskuensi adanya lebih dari satu akad, jika digambarkan maka akad Syariah Card adalah sebagai berikut:

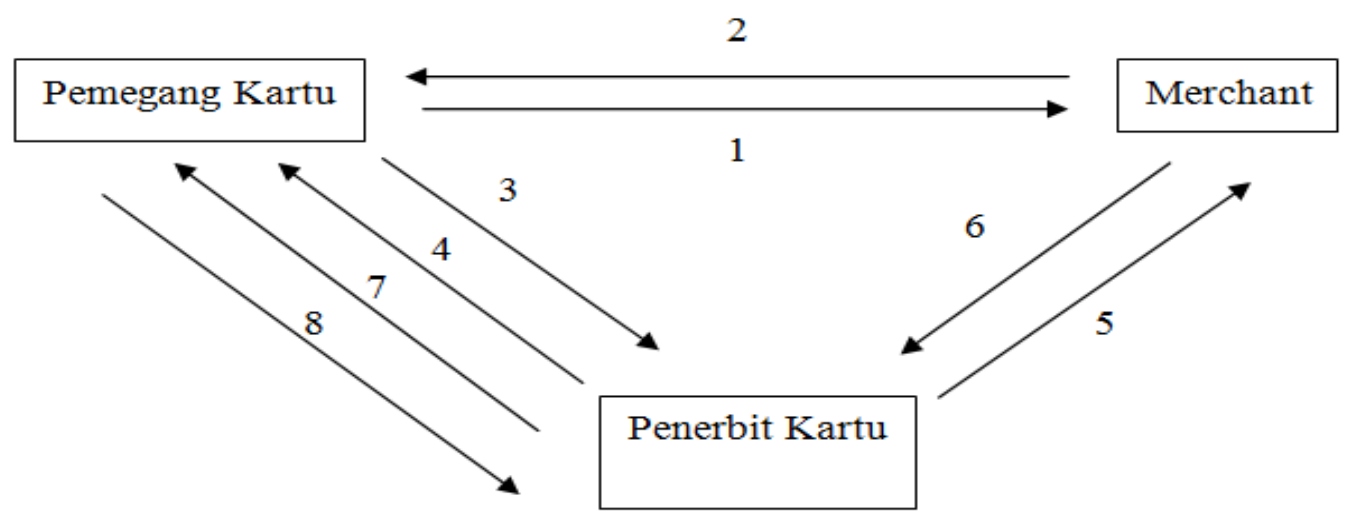

Keterangan:

1. Nasabah mengajukan permohonan sebagai pemegang kartu (card holder) dengan memenuhi segala persyaratan dan peraturan yang telah dibuat oleh bank pembuat kartu. Pada tahap ini terjadi Wa'ad (Janji) dari bank Syariah kepada nasabah untuk memberikan pembiayaan, sehingga akad yang dilakukan adalah jual-beli.

2. Bank atau lembaga pembiayaan akan menerbitkan kartu apabila "disetujui" setelah melalui penelitian terhadap kredibilitas dan kapabilitas calon nasabah, terjadilah akad jual-beli.

3. Dengan kartu kredit yang telah dipegangnya, nasabah dapat melakukan transaksi pembelanjaan barang atau jasa ditempat-tempat yang telah mengikat perjanjian dengan bank, dengan mnunjukkan Syariah Card tersebut sebagai bukti transakasi. Pada tahap ini nasabah bertindak sebagai Wakalh dari bank untuk menggunakan Syariah Card dalam transaksi pembelian barang. 
4. Bank kemudian menjual kembali barang yang dibeli kepada nasabah pemegang. Dari penjualan cicilan inilah bank Syariah mendapatkan Ribhi atau margin.

5. Merchant akan menagih ke bank atau lembaga pembiayaan berdasarkan bukti transaksi nasabah pemegang kartu.

6. Bank atau lembaga pembiayaan akan membayar kembali kepada pedagang sesuai dengan perjanjian yang telah disepakati termasuk fee dan biayabiaya lainnya.

7. Bank akan menagih kepada pemegang kartu berdasarkan bukti pembelian sampai batas waktu tertentu sebagaimana kesepakatan dalam perjanjian.

8. Pemegang kartu akan membayar sejumlah nominal yang tertera di dalamnya sudah termasuk Ribhi, sampai pada batas waktu yang telah ditentukan, dan apabila terjadi keterlambatan, maka pemegang kartu akan dikenai denda sejumlah tertentu sesuai kesepakatan dalam akad. ${ }^{13}$

Jadi, jika diperhatikan lebih mendalam, terdapat tiga ketentuan akad yang digunakan dalam produk Syariah Card ini, yaitu sebagai berikut: Pertama, akad Kafalah, akad ini digunakan antara penerbit kartu dengan Merchant. Dalam hal ini penerbit kartu adalah penjamin (kafil) bagi pemegang kartu terhadap merchant atas semua kewajiban bayar (dayn) yang timbul

${ }^{13}$ Arif Pujiono. 2005. Islamic Credit Card (Suatu Kajian terhadap Sistem Pembayaran Islam Kontemporer). Jurnal Dinamika Pembangunan Vol. 2 No. 1 / Juli 2005. Hal. 67. dari transaksi antara pemegang kartu dengan merchant, dan/ atau penarikan tunai dari selain bank atau ATM bank penerbit kartu. Atas pemberian kafalah, penerbit kartu dapat menerima (ujrah kafalah).

Kedua, Akad Qard. Akad ini digunakan antara penerbit kartu dengan pemegang kartu. Dalam hal ini penerbit kartu adalah pemberi pinjaman (Muqridh) kepada pemegang kartu (Muqtaridh) melalui penarikan tunai dari bank atau ATM bank penerbit kartu.

Ketiga, Akad Ijarah. Akad ini digunakan antara penerbit kartu dengan pemegang kartu. Dalam hal ini penerbit kartu adalah penyedia jasa sistem pembayaran dan pelayanan terhadap pemegang kartu. Atas ijarah ini, pemegang kartu dikenakan membership fee.

\section{B. Polemik Seputar Syariah Card}

Adanya fakta bahwa Syariah Card (Kartu Krdit Syariah) memang banyak dibutuhkan karena esensinya yang bersifat praktis, aman, dan fleksibel juga keran fungsinya dapat memberikan proteksi keuangan berupa adanya keperluan mendadak dan kemudahan bertransaksi bagi masyarakat. Bagi perbankan Syariah kehadiran Syariah Card sudah tentu menjadi bentuk layanan kepada nasabah yang ingin memproleh kemudahan seperti Convenience Product dalam menjaga loyalitas nasabah. Di sisi lain pro-kontra munculnya fatwa tentang Syariah Card oleh DSN MUI tidak serta merta berakhir.

Berbagai permasalahan pada munculnya produk Syariah Card adalah sebagai berikut. Pertama, adanya Charge yaitu Late charge atau denda karena 
keterlambatan pembayaran dan ada juga Ta'wid (ganti rugi) memunculkan pertanyaan apakah perbedaan yang mendasari denda dalam Syariah Card dan Kartu Kredit Konvensional.

Pengenaan ta'wid banyak kontroversi ulama' tentang prmasalahan ini, ada yang memperbolehkan dan ada pula yang melarang adanya ta'wid. Beberapa pendapat tentang ta'wid yang diterapkan dalam bank Islami adalah sebagai berikut. Menurut ijtihad Kamal Hammad, hanya mahkamah yang berwenang untuk memberikan hukuman terhadap nasabah defaul payment. Ia menolak dengan tegas hukuman terhadap nasabah defaul payment dengan kompensasi. Sementara ijtihad saintifik Syaykh Mustafa al-Zarqa', sebagaimana dikutip Mohammad Ali Elgari et.al, berpendapat bahwa hukuman denda mesti diputuskan oleh mahkamah tinggi saja dan uang denda itu mesti dimanfaatkan untuk kepentingan sosial. Bank Syari'ah tidak boleh mengambil uang denda tersebut, tetapi semua uang denda itu mesti dimanfaatkan untuk maslahah 'ammah (public interest). ${ }^{14}$

Sementara ijtihad saintifik kolektif Islamic Fiqh Academy, mengeluarkan fatwa bahwa jika nasabah gagal membayar angsuran pada waktu yang telah disepakati, maka pihak bank tidak boleh mengenakan denda atau bayaran lain atas kegagalan tersebut, kerana hal itu sama saja dengan menerapkan konsep bunga terhadap angsuran tersebut. $^{15}$

${ }^{14}$ Nur Kholis. Urgensi Ijtihad Saintifik Dalam Menjawab Problematika Hukum Transaksi Kontemporer. Makalah. E book. Hal. 11-12.

${ }^{15}$ Ibid
Sedangkan menurut al-Sadiq al-Darir berpendapat denda terhadap defaul payment dengan syarat jumlah denda itu tidak melebihi jumlah hutang nasabah diperbolehkan. Muhammad Taqi Usmani mendukung pendapat ini, yaitu nasabah defaul payment atau tai'wid hendaknya membayar sejumlah uang kepada institusi kebajikan yang dimiliki oleh bank Islam untuk tujuan membiayai kegiatan kebajikan yang dibolehkan oleh Syari'ah. Bank Islam tidak boleh mendapat bagian sedikitpun dari uang denda tersebut. Jadi uang denda itu bukan kompensasi kepada pembiaya (bank Islam) sebagai opportunity cost, tetapi semata-mata untuk tujuan kebajikan. ${ }^{16}$

Sedangkan Umer Chapra dan Tariqullah Khan menyatakan bahwa kalau defaul payment tidak dikenakan penalti atau denda maka hal ini akan menjadi satu fenomena dan preseden yang tidak baik bagi kelangsungan ekonomi sosial, dan orang yang defaul payment tersebut akan terusmenerus melakukan ketidakjujuran. Hal ini juga akan memperburuk sistem keuangan suatu institusi keuangan apalagi kalau nilai kontrak itu sangat besar. Oleh karena itu, Umer Chapra dan Khan mengusulkan konsep "Loss Given Default" (LGD) untuk menentukan jumlah kompensasi agar bisa mengkurangkan nilai-nilai ketidakadilan antara pihak nasabah dan bank Islam saat terjadi defaul payment dengan syarat jumlah kompensasi sudah disetujui oleh ulama, dalam hal ini adalah Dewan Penasehat Syari'ah Nasional. ${ }^{17}$

Sedangkan menurut Joni Tamkin bin Borhan berpndapat, bahwa pengenaan ganti 
rugi (ta'wid mali) menurut penelitian sebagian pakar ekonomi Islam adalah dibolehkan dengan argumen-argumen berikut: (1) Di antara inti hukum Islam adalah konsep "penolakan madarat" di mana setiap madarat atau kerugian mestilah dihindari. (2) Praktek riba hanya terjadi dalam hal pertukaran uang dengan uang atau barang ribawi dengan barang ribawi. Dalam kasus pengenaan bayaran ganti rugi, ia dikenakan ke atas kegagalan nasabah dalam akad pertukaran (mu'awadah) yang melibatkan pertukaran antara uang dengan barang yaitu dari jenis dan sifat yang berbeda. Dalam hal ini terdapat ijtihad fiqhi berhubung dengan bay' al-'arbun dan kebolehan hangusnya uang deposit karena untuk mengganti kerugian penjual menunggu dan tidak memasarkan barang yang ditempah itu kepada pelanggan lain. Kerugian dalam kasus bay' al-'arbun adalah berbentuk kerugian ekonomi, sementara kerugian yang ditanggung oleh investor dan penabung akibat defaul payment adalah berbentuk kerugian riil. (3) Riba selalu memberi kelebihan satu pihak ke atas pihak lain, sementara bayaran ganti rugi hanya sekedar mengembalikan keadaan kerugian kepada keadaan tidak rugi. Ini tidak menguntungkan pihak bank, kerana tujuan ganti rugi hanya sekedar memperbaiki keadaan. ${ }^{18}$

Untuk permasalahan Syariah Card ini maka pendapat di ambil pendapat Umar Chapra dan Thariqul Khan. Seharusnya ada kesepakatan Ta'wid agar ketidakadilan dapat dihilangkan. Hal ini sesuai dengan kaidah fikih yang berbunyi:

\footnotetext{
${ }^{18}$ Ibid
}

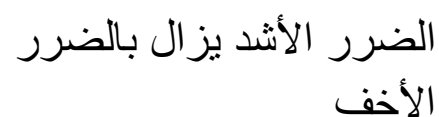

Artinya: "Kemadharatan yang lebih besar/ berat dihilangkan dengan Kemadharatan yang lebih ringan."

Kemudharatan yang lebih besar adalah adanya ta'wid yang memberatkan pada salah satu pihak, sedangkan diadakannya musyawarah dalam penentuan ta'wid agar tidak merugikan salah satu pihak.

Kedua, adanya Syariah Card dengan menggunakan akad jasa (fasilitas) pelayanan perlu adanya kehati-hatian agar tidak masuk dalam lingkaran keharaman dalam hal ini adalah keharaman riba. Munculnya berbagai polemik antara lain pada pemilihan akad, karena akad yang digunakan adalah akad Qard atau pembiayaan maka disyaratkan adanya agunan.

Akad Qard secara harfiah adalah akad dengan prinsip pinjam-meminjam untuk nonbisnis yang harus disertai jaminan. Qard adalah pemberian harta kepada orang lain yang dapat ditagih atau diminta kembali atau dengan kata lain meminjamkan tanpa ada harapan imbalan. Dalam literature fikih klasik qard dikatagorikan dalam akad tathowwui atau akad saling membantu dan bukan bersifat komersial. ${ }^{19}$

Dengan akad Qard, pemegang kartu kredit syariah harus menyetor deposit yang menjadi agunan sekaligus limit kreditnya. Deposit ini disimpan dalam bentuk deposito dan tabungan yang tidak bisa ditarik, hal inipun menjadi identitas adanya Goodwill invsment dari nasabah itu sendiri. Akad Qord memungkinkan pemegang kartu untuk

19 Abdul Aziz dan Maria Ulfah. 2010. Kapita Selekta Ekonomi Islam Kontemporer. (Bandung: Alfabeta). hal. 254 
mencicil uang. Di sini kita dapat melihat adanya sebuah paradoks di sisi lain orang yang menjadi kartu kredit syariah adalah orang yang hendak berhutang tetapi disisi lain justru harus punya uang dulu sebagai bentuk deposit.

Adanya ketidak konsistenan penggunaan istilah dalam fatwa Syariah Card juga menimbulkan kerancuan, istilah yang digunakan adalah akad Qard tetapi pada ketentuan merchant fee terdapat ujrah penagihan atau tahsil al-dayn, disatu sisi menggunakan istilah Qard di sini lain menggunakan istilah dayn. Adanya perbedaan yang sangat tipis ini akan menimbulkan implikasi yang cukup luas.

Qardul hasan sebenarnya adalah akad yang bersifat kerja sama dalam bentuk bantuan uang yang bercondong penggunaannya untuk usaha (produktif). Hal ini berbeda dengan Dayn (utang) yang penggunaannya lebih brsifat kepada konsumtif, dan hal ini secara otomatis berbeda akad. Oleh karena itu, dalam Islam menganjurkan untuk menggunakan sistem kerja sama (Syirkah) dari pada sistem Dayn (utang).

Ketiga, dalam produk kartu kredit syariah tidak ada sistem kontrol yang memastikan apakah pemegang kartu menggunakan kartu kreditnya untuk membelanjakan barang-barang yang halal saja atau tidak, karena selama ini ketika seorang nasabah menggunakan kartu kredit syariah untuk transaksi dengan cara menggeseknya, maka yang tercatat adalah nama merchant bukan nama item barang yang dibeli. Hal ini menjadikan kartu kredit syariah pada penggunaannya rentan terjadi penyelewengan. Maka perlu adanya sesuatu yang dapat menghilangkan kemudharatan tersebut, hal ini sesuai dengan kaidah fikih yang berbunyi:

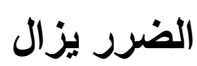

Artinya: "Kemadharatan itu harus dihilangkan.”

Dalam hal yang menyangkut pada kemudharatan ini maka seharusnya pada syariah card ini harus ada badan pengawas yang secara sistemis dapat meminimalisir adanya penyelewengan penggunaan kartu kredit syariah, sehingga kemudharatan yang terjadi dapat dihilangkan.

Keempat, kartu kredit syariah seharusnya tidak boleh menjadikan pemakainya menjadi Isrof (konsumtif/berlebihan), sementara di sisi lain kartu kredit cenderung menjadikan pemegangnya menjadi konsumtif. Dalam hal ini jelas bertentang dengan prinsip syariah. Tetapi pada tataran prakteknya ke-Isrof-an ini dapat diminimalisir dengan adanya pagu limit berdasarkan jenis kartu, yaitu kartu hijau, kartu emas, dan kartu platinum.

Adanya pagu limit ini tidak serta merta memberikan hilangnya kemudharatan, dalam hal ini adalah kemudharatan Isrof, sehingga Isrof akan tetap terjadi meskipun adanya pagu limit. Sebuah penciptaan produk diperbankan syariah seharusnya didasarkan pada tujuan produk itu diciptakan yaitu menghindarkan dari Riba, Gharar, Israf atau Konsumsi yang berlebihan, eksploitasi, dan lain sebagainya. Jika dilihat aspek tujuan adanya suatu produk maka ada kecocokan kaidah fikih yang mengatakan:

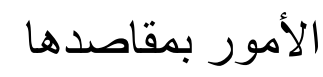

Artinya: " Setiap perkara (perbuatan) itu tergantung pada tujuannya." 


\section{KESIMUPULAN DAN SARAN}

Dilihat dari berbagai aspek memang Syariah Card dapat dibenarkan secara ilmu Fikih tetapi pelaksanaannya harus mmenuhi syarat-syarat yang menyertainya.

Tidak semua yang ada di perbankan konvensional harus diadopsi oleh perbankan syariah. Hal ini dikhawatirkan pada masa yang akan datang produk syariah dinilai hanya skedar labelisasi saja. Kartu kredit syariah yang tidak menggunakan suku bunga dalam pembayarannya bukan berarti diperbolehkan dalam presfektif islam, tetapi harus dilihat dari berbagai aspek misal segmen pasar, perilaku nasabah, dan adat atau kebiasaan nasabah yang menyertainya. Sehingga kebaikan dari berbagai aspek dapat memberikan solusi bagi kebaikan umat Islam.

Skala prioritas seharusnya diterapkan sehari-hari oleh umat muslim. Sehingga dapat meminimalisir suatu hal yang bersifat isrof. Dalam hal ini penggunaan kartu kredit syariah bukanlah pada tingkatan Dharuriyah (primer) karena selama masih ada jenis pembiayaan lain yang lebih mudah diterima (oleh Syar'i) seperti kartu debit, kartu ini tidak diperlukan.

\section{DAFTAR PUSTAKA}

Abdul Aziz dan Maria Ulfah. 2010. Kapita Selekta Ekonomi Islam Kontemporer. Bandung: Alfabeta

Adiwarman Karim. 2005. Bank Dan Lembaga Keuangan Lainnya. Jakarta: PT Grafindo Persada.

Al Qur'an al-Karim, Terjemahan Depag.
Arif Pujiono. 2005. Islamic Credit Card (Suatu Kajian terhadap Sistem Pembayaran Islam Kontemporer). Jurnal Dinamika Pembangunan Vol. 2 No. 1/Juli 2005.

caroline. 2010. Penerapan Kartu Kredit Syariah (Hasanah Card). Skripsi. Jakarta. FHUI. Makalah tidak dipublikasikan.

Fatwa Dewan Syari'ah Nasional No: 54/DSN-MUI/X/2006 Tentang Syariah Card

Fatwa DSN No. 9/DSN-MUI/IV/2000 tentang Pembiayaan Ijarah

Fatwa DSN No.11/DSN-MUI/IV/2000 tentang Kafalah

Fatwa DSN No.19/DSN-MUI/IV/2001 tentang Qardh;

Fatwa DSN No.43/DSN-MUI/VIII/2004 tentang Ta'widh

http://www.suarakaryaonline.com/news.html?id=306616

http://www.indonesiafinancetoday.com/read/ 15109/Bisnis-Kartu-PembiayaanBank-Syariah-Melebihi-Target, diakses pada 30 Juli 2012.

Muhammad Syafi'I Antonio, 1999, Bank Syariah (Wacana ulama dan cendekiawan), Jakarta: Tazkia Institut, 
Muhammad Khalid Mas'ud, 1995. Filsafat Hukum Islam dan Perubahan Sosial, terjemahan oleh Yudian W. Asmin, Surabaya: Al Ikhlas.

Muhammad Said Romadlon al Buthi, 1992, Dhowabit al Mashlahah fi al Syariah al Islamiyah, Beirut: Dar al Muttahidah.

Nur Kholis. Urgensi Ijtihad Saintifik Dalam Menjawab Problematika Hukum Transaksi Kontemporer. Makalah. Versi E book.

Peunoh Dali, 1988, Menelusuri Pemikiran Mashlahat dalam Hukum Islam, dalam Iqbal Abdurrauf Saimina (ed), Polemik Reaktualisasi Ajaran Islam, Jakarta: Pustaka Panjimas.

Peraturan Bank Indonesia Nomor 11/11/PBI/2009 tentang Penyelenggaraan Alat Pembayaran dengan Menggunakan Kartu.

Sayyid Abbas Musawiyan. 2012. Sistem Perbankan Islam Berkaca Pada Iran, Jakarta: Sadra Press

Wahbah Zuhaili, 1986, Ushul Fiqh Islamy, juz 2, Damaskus: Dar al Fikr.

Wiroso. 2009. Produk Perbankan Syariah. Jakarta: LPFE Usakti.

Zaim Saidi, 2010, Tidak Syar'inya Bank Syari'ah di Indonesia (dan jalan keluarnya menuju muammalat), Yogyakarta: Delokomotiv. 